\title{
Rosmarinic Acid/ Blue Light Combination Treatment Inhibits Head and Neck Squamous Cell Carcinoma In Vitro
}

\author{
CHRISTI N. WAER, PREET KAUR, ZOHRA TUMUR, DEE DEE HUI, BONNIE LE, \\ CARLOS GUERRA, BRADLEY HENSON, DALIA SELEEM and JILL LEWIS
}

College of Dental Medicine, Western University of Health Sciences, Pomona, CA, U.S.A.

\begin{abstract}
Background/Aim: This study investigated a novel combined therapy of rosmarinic acid (RA)/blue light on head and neck squamous cell carcinoma (HNSCC) cell proliferation in vitro. Materials and Methods: HNSCC cells were exposed to $B L\left(500 \mathrm{~mW} / \mathrm{cm}^{2}\right)$ for $90 \mathrm{~s}$, and incubated with $80 \mu \mathrm{g} / \mathrm{ml}$ RA for 1 hour. Cell viability was determined after 24 h using WST-1 assay. Western blot was used to detect treatment-induced changes in epidermal growth factor receptor (EGFR) activation. Hydrogen peroxide $\left(\mathrm{H}_{2} \mathrm{O}_{2}\right)$ and nitric oxide levels were quantified using $\mathrm{CM}-\mathrm{H}_{2} \mathrm{DCFH}-\mathrm{DA}$ assays. Apoptosis was assessed using Annexin V/PI staining and flow cytometry. Results: RA/blue light treatment resulted in a significant reduction in cell viability, EGFR activation and $\mathrm{H}_{2} \mathrm{O}_{2}$ levels in all HNSCC cell lines. However, no significant changes in $N O$ production or apoptosis induction were found. Conclusion: RA/blue light effectively decreased HNSCC cell proliferation through reduction in EGFR activation and $\mathrm{H}_{2} \mathrm{O}_{2}$ production, and not via induction of apoptosis.
\end{abstract}

Head and neck squamous cell carcinoma (HNSCC) is the sixth most common type of cancer worldwide, which constitutes approximately $90 \%$ of all head and neck cancers (1). HNSCC tumors tend to have an aggressive nature, leading to a 20 times higher risk of metastasis (2). Historically, the treatment of HNSCC has been surgery and radiotherapy, and in the last several years the integration of surgery, radiotherapy and chemotherapy has become the standard of care (3). Many of the drug treatments required at late stages are intensely toxic, and can cause permanently debilitating side effects or even death (4). For instance,

Correspondence to: Jill Lewis, Ph.D., College of Dental Medicine, Western University of Health Sciences, 309 E. Second Street, Pomona, CA 91766-1854, U.S.A. Tel: +1 9094698257, e-mail: lewisj@westernu.edu

Key Words: Head and neck cancer, phytochemicals, light, EGF receptor, oxidative stress. administration of cisplatin can cause permanent damage to renal, gastrointestinal, and nervous systems $(4,5)$. Current research has begun to shift towards naturally occurring compounds in order to combat these tremendous side effects of cancer medications (6). Many of these compounds have been used in traditional medicines for centuries with very few adverse reactions (7). Furthermore, several studies have shown that there is a lower risk of various cancers developing when plant-derived foods are incorporated into the diet, suggesting that such natural products may have chemopreventative properties (6).

Rosmarinic acid (RA) is a naturally occurring polyphenol compound found in plant species Lamiaceae, which includes the common herbs basil, rosemary, sage, and mint (6). There are multiple biological activities associated with RA, which include anti-inflammatory and antioxidant properties as well as neuro- and hepatoprotective activities $(8,9)$. Such biological activities may render RA to also have an antitumorigenic as well as a chemopreventative role. Multiple studies have been shown that RA has the ability to hinder cancer growth within organs throughout the body (10). One study has revealed that rosemary extract, administered through enriched foods, decreased skin tumor numbers in patients with advanced breast cancer $(10,11)$, suggesting that it reduces metastatic potential. Osakabe et al. have previously shown that pre-treatment with RA reduces reactive oxygen species (ROS) production in mice treated with 12-tetradecanoylphorbol 13-acetate (TPA), which may contribute to its anticarcinogenic property via scavenging of reactive oxygen radicals (6).

It has long been reported that cancers thrive in an oxidative environment (12), making redox status a target for chemotherapeutic agents. Chemotherapeutic drugs have been shown to either increase oxidative stress to toxic levels or to inhibit ROS altogether, which may lead to a decrease in cancer cell proliferation (13). The relationship between hydrogen peroxide and pro-proliferative signaling pathways is well established and largely is a consequence of EGFRNox signaling (14). Epidermal growth factor receptor (EGFR) is a highly expressed receptor tyrosine kinase found 
in a wide variety of tumor cell types, and often is overexpressed in HNSCC (15). Binding of the EGF ligand to the surface receptor leads to downstream activation of proteins that regulate cell proliferation and metastasis (16). Thus, EGFR is considered a key regulatory protein involved in cancer cell survival. Tumur et al. have shown that RA pretreatment significantly reduces EGFR activation in UMSCC-6 cells (17), providing a rationale for RA's antiproliferative effects. Furthermore, RA treatment significantly reduced cell migration, suggesting that RA may reduce tumor metastasis (17).

Blue light (BL) $(400-500 \mathrm{~nm})$ is a commonly used tool in dentistry to catalyze the polymerization of resin composites (18). Most light research has focused on the effects of UV light on tissue damage. However, the effects of quartztungsten-halogen (QTH) BL on biological systems have not been extensively studied. Lewis et al. have previously shown that BL (400-500 nm) exhibits a level of selective toxicity, causing significant reduction in oral cancer cell viability, while having no adverse effects on normal human epidermal keratinocytes (NHEK) (19). BL treatment was also effective in significantly slowing tumor growth in vivo (20). Thus, BL may be beneficial for the treatment of peripheral cancers with little or no effect on normal healthy cells.

To the best of our knowledge, for the first time, this study investigates whether a combination therapy treatment of RA/ BL would have a synergistic inhibitory effect on HNSCC cell proliferation. Furthermore, EGFR, a key regulatory protein in head and neck squamous carcinoma cell proliferation was studied to determine if EGFR activation can be influenced in response to these therapies. Finally, oxidative and nitrosative stress $\left(\mathrm{H}_{2} \mathrm{O}_{2} / \mathrm{NO}\right)$ was assessed, as well as treatment-induced apoptosis.

\section{Materials and Methods}

Reagents. RA was purchased from Sigma-Aldrich (St. Louis, MO, USA). A concentration of $80 \mu \mathrm{g} / \mathrm{ml}$ was used for all experiments. BL was delivered from a QTH dental curing light $\left(500 \mathrm{~mW} / \mathrm{cm}^{2}\right.$; VIP, Bisco, Schaumburg, IL, USA). Fiberoptic tips $(6.4 \mathrm{~mm}$ diameter) were used to uniformly treat cell cultures in a 24- or 96well format at a distance of $7.5 \mathrm{~mm}$ from the medium surface. All antibodies were purchased from Cell Signaling Technology (Danvers, MA, USA).

Cell culture. HNSCC cell lines (UM-SCC-1, UM-SCC-6 and OSC2) were grown in Dulbecco's modified Eagle's medium/F-12 (DMEM/F-12, Thermo Scientific, Rockford, IL, USA) containing $2.5 \mathrm{mM}$ L- glutamine, $15 \mathrm{mM}$ HEPES buffer, $10 \%$ fetal bovine serum, $100 \mu \mathrm{g} / \mathrm{ml}$ penicillin, and $100 \mu \mathrm{g} / \mathrm{ml}$ streptomycin. Human oral keratinocytes (HOK) cells were grown in OKM Growth Medium containing OKGS Supplement (Sciencell, Carlsbad, CA, USA). Cells were trypsinized at $70 \%$ confluency and seeded into 96- or 24-well plates at densities of $5 \times 10^{3}$ or $5 \times 10^{4}$ cells/well, respectively. After seeding, the cells were allowed to attach overnight at $37^{\circ} \mathrm{C}$ with $5 \% \mathrm{CO}_{2}$. Cells were then starved for $2 \mathrm{~h}$ with serum-free DMEM/F12 plus $100 \mu \mathrm{g} / \mathrm{ml}$ penicillin and 100 $\mu \mathrm{g} / \mathrm{ml}$ streptomycin prior to specified wells being treated with $\mathrm{BL}$ $(400-500 \mathrm{~nm})\left(60 \mathrm{~J} / \mathrm{cm}^{2}, 2 \mathrm{~min}\right)$ and incubated at $37^{\circ} \mathrm{C}$ with $5 \%$ $\mathrm{CO}_{2}$ for $1 \mathrm{~h}$. RA $(80 \mu \mathrm{g} / \mathrm{ml}$ in serum-free DMEM/F-12) was added to specified wells (RA and combination treatment) and incubated for the specified time period. For EGFR activation experiments, EGF (100 $\mu \mathrm{g} / \mathrm{ml}$; Sigma-Aldrich) was added $1 \mathrm{~h}$ after BL or combination treatment and cells were harvested 5 min later for protein extraction and western blot analysis.

Cell proliferation. Cell proliferation was assessed using the WST-1 Cell Proliferation assay kit (Roche, Indianapolis, IN, USA). UMSCC-6 cells were treated as described above. At $24 \mathrm{~h}$, WST-1 solution $\left(10 \mu \mathrm{l} /\right.$ well) was added and cells were incubated at $37^{\circ} \mathrm{C}$. Absorbance was measured using a microplate reader at $460 \mathrm{~nm}$ at 1,2 , and $3 \mathrm{~h}$ time points.

Western blot analysis. Cells were washed twice with ice cold PBS, then scraped into RIPA buffer (Thermo Scientific) containing phosphatase and protease inhibitor cocktails (Halt ${ }^{\mathrm{TM}}$; Thermo Scientific), transferred to microfuge tubes, and incubated on ice for $5 \mathrm{~min}$. Cell membranes were removed by centrifugation for $20 \mathrm{~min}$ at $4 \mathrm{oC}$ at $12000 \mathrm{rpm}$ and protein concentration of the supernatant was determined using the Coomassie Bradford protein assay (Thermo Scientific). Proteins $(25 \mu \mathrm{g})$ were separated by electrophoresis on $8 \%$ SDS-PAGE gels and transferred to PVDF membranes (BioRad, Hercules, CA, USA). Total EGFR and activated EGFR were detected with primary antibodies specific for EGFR (D38B1; 1:500) and phospho-EGFR (Y992; 1:500). Glyceraldehyde 3-phosphate dehydrogenase (GAPDH) was used as a loading control and detected with anti-GAPDH (14C10; 1:2500). Secondary antibodies conjugated to IRDye ${ }^{\circledR}(1: 10000$; LI-COR, Lincoln, NE, USA) were used to detect protein-primary antibody complexes. Membranes were scanned on the LI-COR Odyssey imaging system and band densities were calculated using ImageJ software.

Hydrogen peroxide assay. Hydrogen peroxide was measured at 24 $\mathrm{h}$ post-treatment in untreated control, BL-treated, RA-treated, and combination treated UM-SCC-6 cells using the Amplex ${ }^{\circledR}$ Red Hydrogen Peroxide Assay Kit (Thermo Fisher Scientific, Waltham, MA, USA) as described by the manufacturer's instructions. The results were read on a microplate reader with an emission of 590 $\mathrm{nm}$ and excitation of $560 \mathrm{~nm}$.

Nitric oxide assay. Nitric oxide levels were assessed in UM-SCC-6 cells immediately after treatment using 4-amino-5-methylamino-2', 7'difluorofluorescein diacetate (DAF-FM diacetate) reagent ( $5 \mu \mathrm{M}$; Molecular Probes Life Technologies, Eugene, OR, USA). The DAFFM diacetate was added immediately following treatment and the cells were incubated for $20 \mathrm{~min}$ at $37^{\circ} \mathrm{C}$. The cells were washed twice with 1X PBS, incubated in 1X Dulbecco's PBS for $15 \mathrm{~min}$, and then fluorescence was read on a microplate reader with excitation at 495 $\mathrm{nm}$ and emission at $515 \mathrm{~nm}$.

Flow cytometry. UM-SCC-6 cells were seeded at a density of 50,000 cells in $1 \mathrm{ml}$ DMEM/F-12 in 24-well plates and allowed to attach overnight. The cells were then treated with BL, RA and combination, 


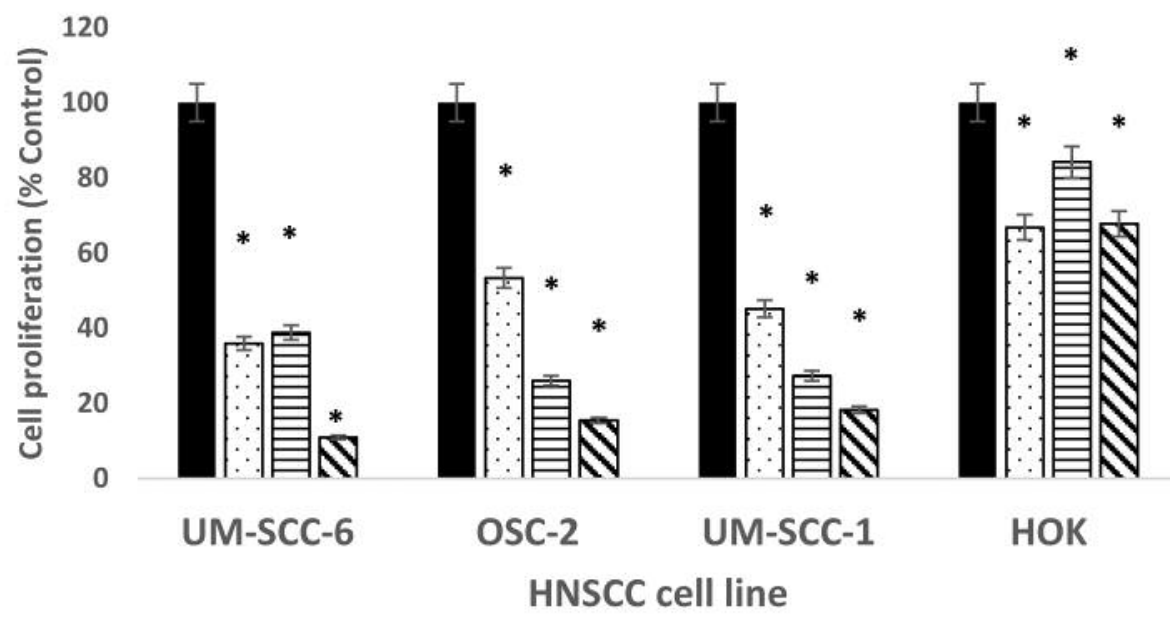

- Control פRA 日BL $\Delta R A+B L$

Figure 1. WST-1 cell proliferation assay of various HNSCC cell lines: UM-SCC-6, OSC-2, UM-SCC-1 and normal HOK cells 24 host-treatment with $R A, B L$, and RA+BL. Data are expressed as \% control (set at 100\%) $\pm S D$.

and incubated again for a 12-h period. For positive control, $1 \mu \mathrm{M}$ staurosporine (STS; ApexBio, Taiwan) was used to induce apoptosis. At $12 \mathrm{~h}$, the cells were harvested and prepared for flow cytometry using the Annexin V Apoptosis Detection Kit (Thermo Fisher Scientific) following the manufacturer's instructions. In the Annexin $\mathrm{V}$ vs. propidium iodide (PI) plot, the FL4-A filter was used for Annexin V and FL2-A filter was used for PI.

Statistical analysis. Data were expressed as mean \pm SD. One-way ANOVA test was performed to compare the values between the groups. Results were considered statistically significant when $p$ values were less than 0.05 .

\section{Results}

$R A, B L$ and combination treatments reduced the growth rate of HNSCC cell lines. The effects of RA and BL alone and in combination were tested on three HNSCC cell lines - UMSCC-1, UM-SCC-6, and OSC-2 - and compared to their effects on normal human oral keratinocytes (HOK). All HNSCC cell lines tested showed significant reductions in cell proliferation $24 \mathrm{~h}$ following each single treatment of RA (47-64\% reduction) or BL $(61-74 \%$ reduction) when compared to untreated controls (Figure 1). In addition, in each case the combination treatment was significantly more effective (82-89\% reduction) than either single therapy alone. However, there was a much less dramatic effect on HOK, with RA or BL single treatment reducing proliferation by $34 \%$ and $16 \%$, respectively. In addition, there was no additive or synergistic effect of the dual therapy, suggesting a reduced sensitivity to these treatments in normal noncancerous cells.

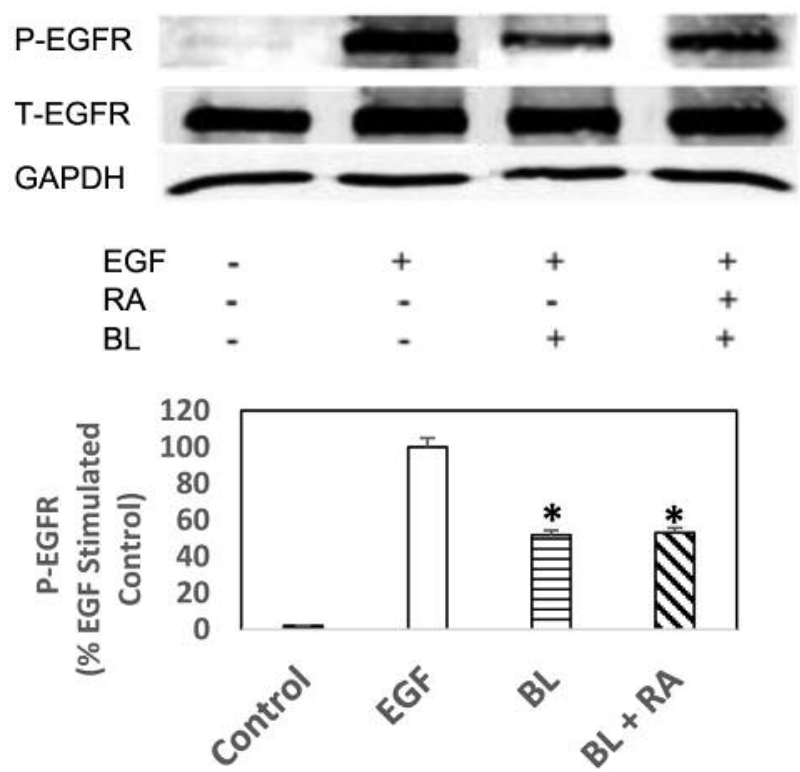

Figure 2. Western blot of total and activated (P-EGFR) levels in UMSCC-6 cells. Control (no treatment or EGF stimulation), EGF-stimulated, and EGF-stimulated following pre-treatment with $B L$ or combination $(B L+R A) . * p<0.05$ compared to EGF-stimulated control; $n=3$.

All therapies significantly decreased EGFR activation. Previous studies in our laboratory had reported the significant reduction in EGFR activation resulting from pretreatment with RA (17). We used the same procedure to test the effects of $\mathrm{BL}$ and combination treatment on EGFR 


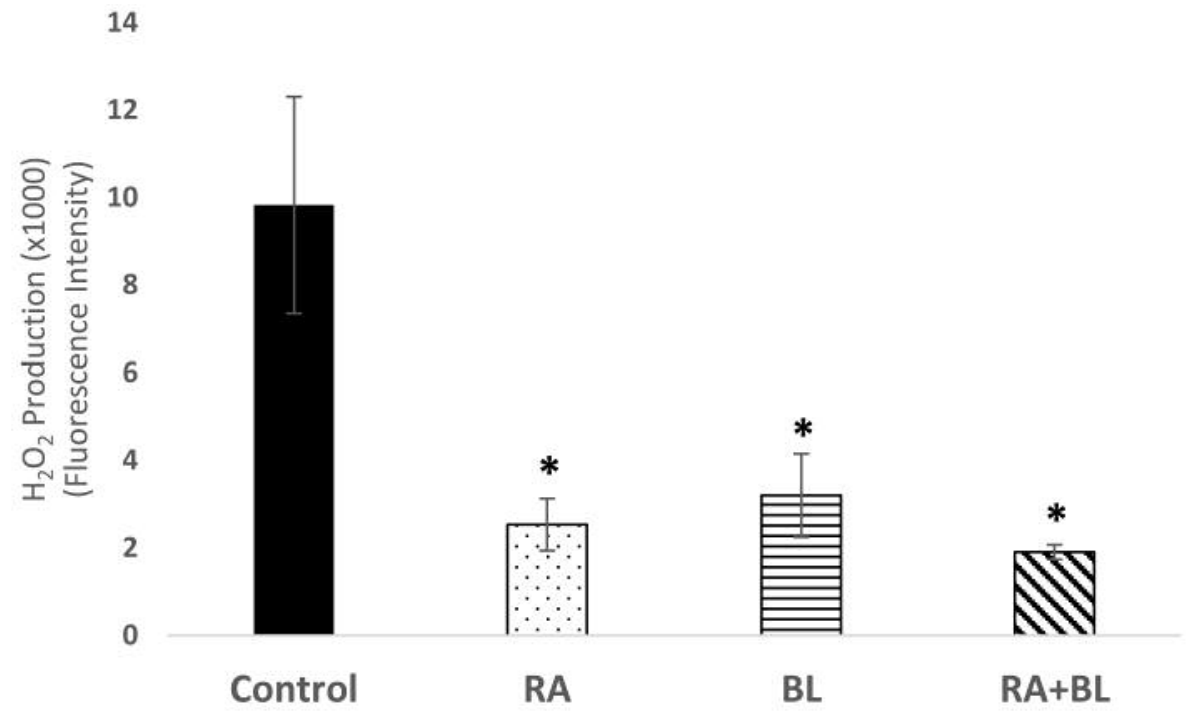

Figure 3. Hydrogen peroxide levels were assessed in UM-SCC-6 cells at 24 h post-treatment using Amplex Red. All treatments significantly reduced hydrogen peroxide levels; $n=6(* p<0.05)$.

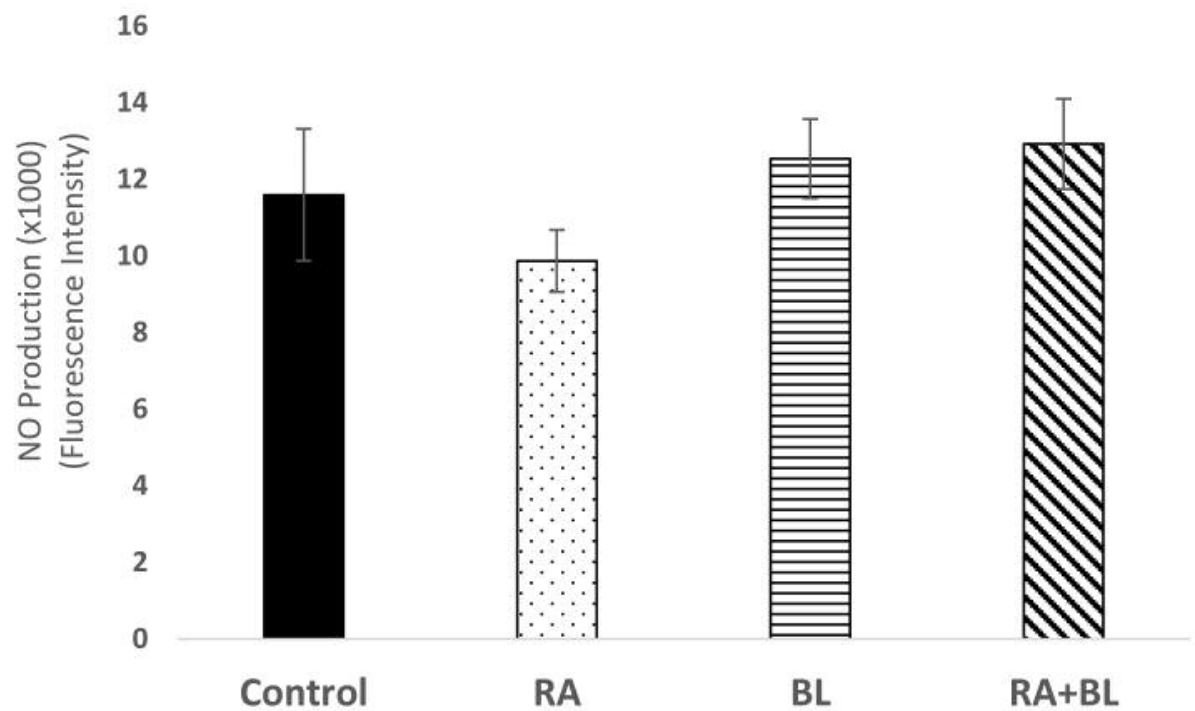

Figure 4. Nitric oxide levels were assessed immediately after treatment by addition of DAF-FM diacetate reagent and fluorescence quantitation (495 $\mathrm{nm}$ excitation/515 $\mathrm{nm}$ emission); $n=6$.

activation. As shown in Figure 2, both BL and RA +BL treatments reduced EGFR activation by $\sim 50 \%$.

All therapies significantly decreased hydrogen peroxide levels. Hydrogen peroxide $\left(\mathrm{H}_{2} \mathrm{O}_{2}\right)$ can be found constitutively activated in cancer cells leading to increased cell proliferation and survival (21). This constant activation can be a direct outcome of EGFR signaling due to increases in $\mathrm{NAD}(\mathrm{P}) \mathrm{H}$ oxidase (NOX) signaling, which leads to the production of superoxide ions $\left(\mathrm{O}_{2}^{-}\right)$that can then be converted to $\mathrm{H}_{2} \mathrm{O}_{2}$ through superoxide dismutase (SOD) (22). At $24 \mathrm{~h}$ after treatment, RA and BL reduced $\mathrm{H}_{2} \mathrm{O}_{2}$ production by $\sim 4$ - and 3-fold, respectively, while the combination treatment reduced $\mathrm{H}_{2} \mathrm{O}_{2}$ levels by $\sim 5$-fold (Figure 3). BL and RA may be blocking growth factor signaling and over-activating catalase, peroxiredoxins and 

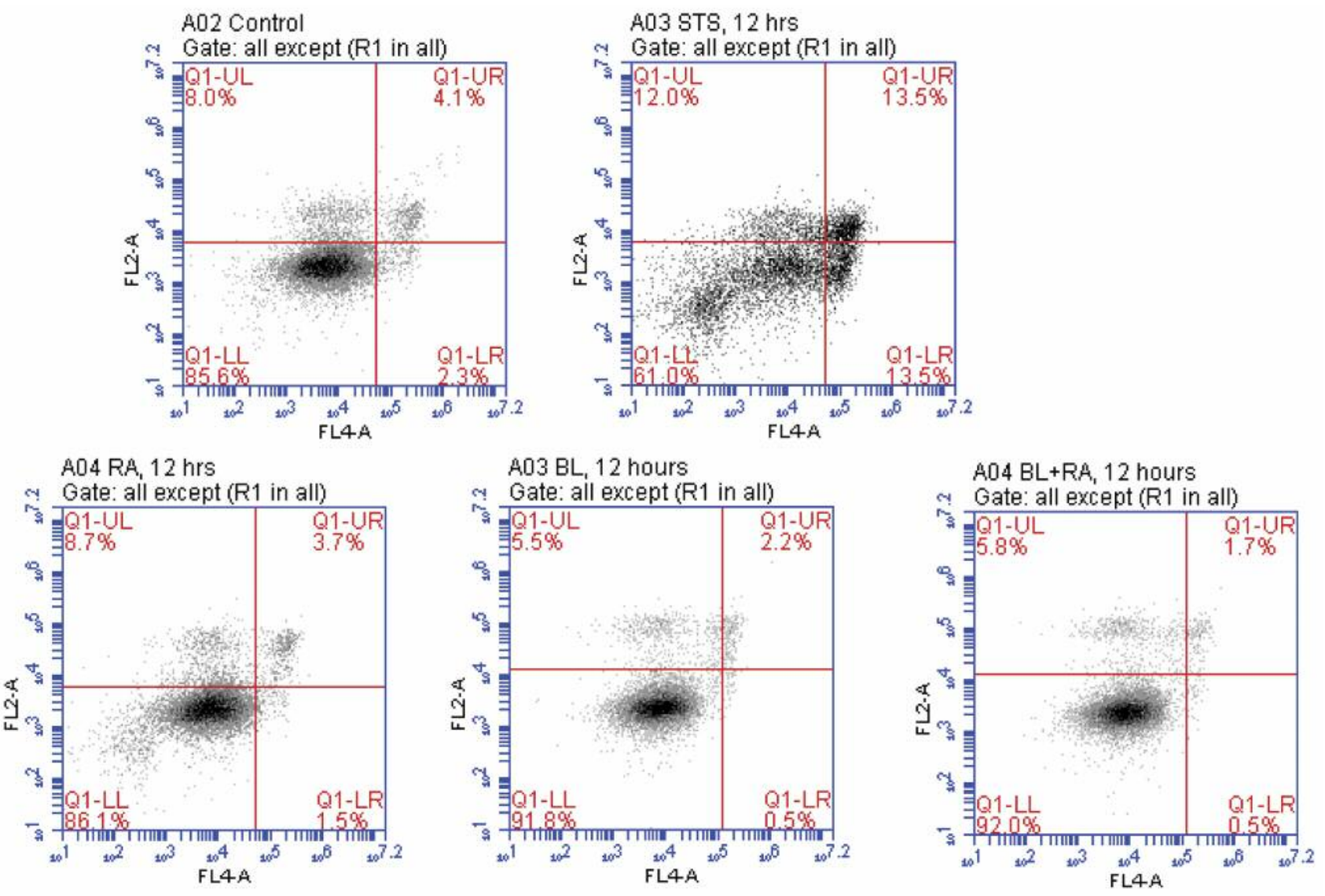

Figure 5. Flow cytometric analysis of AnnexinV/PI-stained UM-SCC-6 cells treated with RA, BL or combination compared to untreated negative control and staurosporine-treated (STS) positive control profiles at $12 \mathrm{~h}$ after treatment.

glutathione peroxidases that would result in the observed $\mathrm{H}_{2} \mathrm{O}_{2}$-scavenging effect (23).

BL enhanced nitric oxide production, while RA is a nitric oxide scavenger. As shown in Figure 4, BL slightly enhanced production of nitric oxide when compared to untreated control cells, although the effect was not statistically significant. This effect was evident in both single and combination treatment groups. Conversely, RA decreased nitric oxide production, though not significantly.

Neither treatment induced apoptosis or necrosis in UMSCC-6 cells. Flow cytometric analysis of Annexin $\mathrm{V} /$ propidium iodide stained cells showed no evidence of increased levels of apoptosis or necrosis in cells treated with RA, BL, or combination treatment (Figure 5). Profiles for all treatment groups were nearly identical to that of the untreated controls, while staurosporine treated cells showed significantly increased levels of apoptotic and necrotic cells.

\section{Discussion}

The aim of this study was to provide a scientific foundation for the use of BL and RA as an effective adjunctive treatment for HNSCC. The mechanisms underlying the effects of these treatments on cell proliferation of oral carcinoma were investigated by exploring EGFR activation, oxidative/nitrosative stress $\left(\mathrm{H}_{2} \mathrm{O}_{2} / \mathrm{NO}\right)$, and induction of apoptosis.

The last truly established therapy for HNSCC, EGFRtargeting monoclonal antibody cetuximab, appeared in 2006 (15). Epidermal Growth Factor Receptor is a cell-surface protein of the erbB family of receptor tyrosine kinases that regulates cell growth and differentiation (24). EGFR has been noted to contribute to proliferation and invasion of cancer cells and has been indicated to be overexpressed in $90 \%$ of HNSCC (25). Both RA and BL treatments significantly reduced EGFR activation and therefore could be important non-toxic components in HNSCC therapies.

Cancer cells are generally known for a marked increase in ROS levels, both as a result of an increase in metabolism and 
as a signaling system for cell proliferation (26). ROS is primarily compartmentalized within mitochondria since it is generated as a by-product of the electron transport system. This process releases $0.4-4.0 \%$ of consumed oxygen back into the mitochondria as hydrogen peroxide $\left(\mathrm{H}_{2} \mathrm{O}_{2}\right)$, superoxide $\left(\mathrm{O}_{2}^{-}\right)$, singlet oxygen $\left(\mathrm{O}^{-}\right)$, or the hydroxyl radical $(27,28)$. Anticancer therapies can be designed to increase the overall ROS to toxic levels and create debilitating cell damage, leading to the induction of apoptosis or senescence (26). Several studies have shown that increases in intracellular ROS create an $\mathrm{H}_{2} \mathrm{O}_{2}$ dependent induction of apoptosis (29). For instance, a non-steroidal anti-inflammatory, sulindac, has been studied as a potential treatment for colon and lung cancers due to its ability to increase intracellular ROS, resulting in a $\mathrm{H}_{2} \mathrm{O}_{2}$ dependent induction of apoptosis (30). Conversely, reduction of $\mathrm{H}_{2} \mathrm{O}_{2}$ diminishes the proliferative signal associated with growth factor activation and could reduce proliferation or induce cell senescence. RA has been shown to induce a nominal increase in antioxidative enzymes, which may contribute to RA being anti-tumorigenic (6). A similar antioxidant, genistein, has also been shown to have anticarcinogenic properties through its ability to decrease $\mathrm{H}_{2} \mathrm{O}_{2}$ formation in an in vivo and in vitro study (31). Similar studies using antioxidant compounds, such as caffeic acid phenethyl ester, have resulted in a decrease in hydrogen peroxide levels through a scavenging mechanism that reduced cell growth within human leukemic HL-60 cells $(9,32)$. Likewise, BL has been shown to induce the production of peroxiredoxins in human THP-1 monocytic cells, thus suggesting an antioxidant effect of this treatment (19). Although neither treatment significantly altered NO levels, both behaved as has been previously reported. BL has reportedly increased intracellular NO levels through direct, non-enzymatic release of NO from photolabile nitrosylated proteins (33), while RA has been identified as a NO scavenger $(34,35)$. Alterations in NO signaling can have far-reaching effects. For example, there is evidence to support that NO has inhibitory effects on NFkB DNA binding (36). Downregulation of NFkB downstream targets may serve to decrease cancer cell proliferation and metastasis.

Our results showed that both RA and BL significantly decreased cell proliferation in all HNSCC cell lines tested (Figure 1). In addition, the combination therapy was significantly more effective than either single treatment alone. It is important to note that normal human oral keratinocyte cells (HOK) were much less affected by the treatments than the tumor cell lines (Figure 1), suggesting that this combination treatment has the potential to inhibit cancer cell proliferation and growth, while resulting in minimal toxicity to normal healthy cells. Not surprisingly, the decrease in cell proliferation of UM-SCC-6 cells illustrated in Figure 1 correlated with the downregulation in
EGFR activation (Figure 2) and the reduction in $\mathrm{H}_{2} \mathrm{O}_{2}$ levels (Figure 3) resulting from RA and BL treatment. No evidence for these treatments causing an induction in apoptosis was found (Figure 5). Taken together, these data suggest that the combination treatments are synergistically working to inhibit growth factor signaling and possibly inducing cell cycle arrest or cell senescence $(19,37)$.

In conclusion, to the best of our knowledge, this is the first study that confirms that treatments of $\mathrm{BL}$ in conjunction with RA inhibited cell proliferation in HNSCC cell lines. The underlying mechanisms have yet to be fully explored, but our findings to date suggest that these treatments show promise. Future studies will examine whether this combination treatment may provide means to reduce therapeutic doses of traditional chemotherapeutics, such as cisplatin, and thus diminish the debilitating side effects of these drugs.

\section{Conflicts of Interest}

There are no conflicts of interest related to this study.

\section{Authors' Contributions}

MSBS graduate students Christi Waer and Preet Kaur performed most of the experiments. Dental students DeeDee Hui and Bonnie Le received the Western University Summer Research Fellowship and performed the initial cell proliferation analyses. Carlos Guerra contributed to organization and performance of experiments as laboratory manager/research assistant. Drs. Lewis, Henson and Tumur contributed equally to experimental design and data analysis. Dr. Dalia Saleem contributed to statistical analysis and preparation of the manuscript.

\section{Acknowledgements}

The Authors thank Dr. Stephen Hsu for providing the OSC-2 cell line, the Western University of Health Sciences Intramural Research Grant Award IMR12342D, the Western University of Health Sciences Summer Student Fellowship Grant and the College of Dental Medicine for support of this research.

\section{References}

1 Vigneswaran $\mathrm{N}$ and Williams MD: Epidemiologic trends in head and neck cancer and aids in diagnosis. Oral Maxillofac Surg Clin North Am 26(2): 123-141, 2014. PMID: 24794262. DOI: 10.1016/j.coms.2014.01.001

2 Kulasinghe A, Perry C, Jovanovic L, Nelson C and Punyadeera C: Circulating tumor cells in metastatic head and neck cancers. Int J Cancer 136(11): 2515-2523, 2015. PMID: 25111594. DOI: 10.1002/ijc. 29108

3 Georges P, Rajagopalan K, Leon C, Singh P, Ahmad N, Nader $\mathrm{K}$ and Kubicek GJ: Chemotherapy advances in locally advanced head and neck cancer. World J Oncol 5(5): 966-972, 2014. PMID: 25493232. DOI: 10.5306/wjco.v5.i5.966 
4 Domitrovic R, Potocnjak I, Crncevic-OrlicZ and Skoda M: Nephroprotective activities of rosmarinic acid against cisplatininduced kidney injury in mice. Food Chem Toxicol 66: 321-328, 2014. PMID: 24518541. DOI: 10.1016/j.fct.2014.02.002.

5 Lee YM, Auh QS, Lee DW, Kim JY, Jung HJ, Lee SH and Kim EC: Involvement of Nrf2-mediated upregulation of heme oxygenase-1 in mollugin-induced growth inhibition and apoptosis in human oral cancer cells. Biomed Res Int 2013: 210604, 2013. PMID: 23738323. DOI: 10.1155/2013/210604.

6 Osakabe N, Yasuda A, Natsume $M$ and Yoshikawa T: Rosmarinic acid inhibits epidermal inflammatory responses: anticarcinogenic effect of Perilla frutescens extract in the murine two-stage skin model. Carcinogenesis 25(4): 549-557, 2004. PMID: 14729597. DOI: 10.1093/carcin/bgh034

7 Li W, Li C, Zheng H, Chen G and Hua B: Therapeutic targets of Traditional Chinese Medicine for colorectal cancer. J Tradit Chin Med 36(2): 243-249, 2016. PMID: 27400481. DOI: 10.1016/s0254-6272(16)30034-6

8 Venkatachalam K, Gunasekaran S, Jesudoss VAS and Namasivayam N: The effect of rosmarinic acid on 1,2-dimethylhydrazine induced colon carcinogenesis. Exp Toxicol Pathol 65(4): 409-418, 2013. PMID: 22236574. DOI: 10.1016/j.etp.2011.12.005

9 Yang SY, Hong CO, Lee GP, Kim CT and Lee KW: The hepatoprotection of caffeic acid and rosmarinic acid, major compounds of Perilla frutescens, against t-BHP-induced oxidative liver damage. Food Chem Toxicol 55: 92-99, 2013. PMID: 23306788. DOI: 10.1016/j.fct.2012.12.042

10 Ngo SN, Williams DB and Head RJ: Rosemary and cancer prevention: preclinical perspectives. Crit Rev Food Sci Nutr 51(10): 946-954, 2011. PMID: 21955093. DOI: 10.1080/10408398. 2010.490883

11 Huang MT, Ho CT, Wang ZY, Ferraro T and Lou YR: Inhibition of skin tumorigenesis by rosemary and its constituents carnosol and ursolic acid. Cancer Res 54(3): 701-708, 1994. PMID: 8306331.

12 Toyokuni S, Okamoto K, Yodoi J and Hiai H: Persistent oxidative stress in cancer. FEBS Lett 358(1): 1-3, 1995. PMID: 7821417. DOI: 10.1016/0014-5793(94)01368-b

13 Udensi UK and Tchounwou PB: Dual effect of oxidative stress on leukemia cancer induction and treatment. J Exp Clin Cancer Res 33: 106, 2014. PMID: 25519934. DOI: 10.1186/s13046014-0106-5

14 Paulsen CE, Truong TH, Garcia FJ and Homann A: Peroxidedependent sulfenylation of the EGFR catalytic site enhances kinase activity. Nat Chem Biol 8(1): 57-64, 2011. PMID: 22158416. DOI: $10.1038 /$ nchembio.736

15 Cassell A and Grandis JR: Investigational EGFR-targeted therapy in head and neck squamous cell carcinoma. Expert Opin Investig Drugs 19(6): 709-722, 2010. PMID: 20415598. DOI: 10.1517/13543781003769844

16 Brand TM, Iida M, Li C and Wheeler DL: The nuclear epidermal growth factor receptor signaling network and its role in cancer. Discov Med 12(66): 419-432, 2011. PMID 22127113.

17 Tumur Z, Katebzadeh S, Guerra C, Bhushan L, Alkam T and Henson BS: RhoC mediates epidermal growth factor-stimulated migration and invasion in head and neck squamous cell carcinoma. Neoplasia 17(1): 141-151, 2015. PMID: 25622907. DOI: $10.1016 /$ j.neo.2014.12.002

18 Rueggeberg FA, Giannini M, Arrais CAG and Price RBT: Light curing in dentistry and clinical implications: a literature review.
Braz Oral Res 31(suppl 1): e61, 2017. PMID: 28902241. DOI: 10.1590/1807-3107bor-2017.vol31.0061

19 Lewis JB, Wataha JC, Messer RL, Caughman GB, Yamamoto T and Hsu SD: BL differentially alters cellular redox properties. J Biomed Mater Res B Appl Biomater 72(2): 223-229, 2005. PMID: 15546154. DOI: 10.1002/jbm.b.30126

20 Patel A, Rotenberg S, Messer RL, Wataha JC, Ogbureke KU, McCloud VV, Lockwood P, Hsu S and Lewis JB: BL activates phase 2 response proteins and slows growth of A431 epidermoid carcinoma xenografts. Anticancer Res 34(11): 6305-6313, 2014. PMID: 25368229.

21 Loo G: Redox-sensitive mechanisms of phytochemical-mediated inhibition of cancer cell proliferation. J Nutr Biochem 14(2): 6473, 2003. PMID: 12667597. DOI: 10.1016/S0955-2863(02)00 251-6.

22 Lien GS, Wu MS, Bien MY, Chen CH, Lin CH and Chen BC: Epidermal growth factor stimulates nuclear factor-kappaB activation and heme oxygenase-1 expression via c-Src, NADPH oxidase, PI3K, and Akt in human colon cancer cells. PLoS One 9(8): e104891, 2014. PMID: 25122478. DOI: 10.1371/journal.pone. 0104891

23 Arnold RS, Shi J, Murad E, Whalen AM, Sun CQ, Polavarapu R, Parthasarathy S, Petros JA and Lambeth JD: Hydrogen peroxide mediates the cell growth and transformation caused by the mitogenic oxidase Nox1. Proc Natl Acad Sci USA 98(10): 55505555, 2001. PMID: 11331784. DOI: 10.1073/pnas.101505898

24 Baselga J and Swain SM: Novel anticancer targets: revisiting ERBB2 and discovering ERBB3. Nat Rev Cancer 9(7): 463-475, 2009. PMID: 19536107. DOI: $10.1038 / \mathrm{nrc} 2656$

25 Kalyankrishna S and Grandis JR: Epidermal growth factor receptor biology in head and neck cancer. J Clin Oncol 24(17): 2666-2672, 2006. PMID: 16763281. DOI: 10.1200/JCO.2005.04.8306

26 Trachootham D, Alexandre J and Huang P: Targeting cancer calls by ROS-mediated mechanisms: a radical therapeutic approach? Nat Rev Drug Discov 8(7): 579-591, 2009. PMID: 19478820. DOI: $10.1038 / \mathrm{nrd} 2803$

27 Nonn L, Berggren M and Powis G: Increased expression of mitochondrial peroxiredoxin-3(thioredoxin peroxidase-2) protects cancer cells against hypoxia and drug-induced hydrogen peroxide- dependent apoptosis. Mol Cancer Res 1(9): 682-9, 2003. PMID: 12861054 .

28 Boveris A: Determination of the production of superoxide radicals and hydrogen peroxide in mitochondria. Methods Enzymol 105: 429-435, 1984. PMID: 6328196. DOI: 10.1016/ s0076-6879(84)05060-6

29 Luo J: Glycogen synthase kinase 3beta (GSK3beta) in tumorigenesis and cancer chemotherapy. Cancer Lett 273(2): 194200, 2009. PMID: 18606491. DOI: 10.1016/j.canlet.2008.05.045

30 Liou GY and Storz P: Reactive oxygen species in cancer. Free Radic Res 44(5): 479-496, 2010. PMID: 20370557. DOI: $10.3109 / 10715761003667554$.

31 Wei H, Wei L, Frenkel K, Bowen R and Barnes S: Inhibition of tumor promoter-induced hydrogen peroxide formation in vitro and in vivo by genistein. Nutr Cancer 20(1): 1-12, 1993. PMID: 8415125.

32 Chen YJ, Shiao MS and Wang SY: The antioxidant caffeic acid phenethyl ester induces apoptosis associated with selective scavenging of hydrogen peroxide in human leukemic HL-60 cells. Anticancer Drugs 12(2): 143-149, 2001. PMID: 11261888. DOI: 10.1097/00001813-200102000-00008 
33 Oplander C, Deck A, Volkmar CM Kirsch M, Liegmann J, Born $M$, van Abeelen F, van Faassen EE, Kroncke KD, Windolf J and Suschek CV: Mechanism and biological relevance of blue-light (420-453 nm)-induced nonenzymatic nitric oxide generation from photolabile nitric oxide derivates in human skin in vitro and in vivo. Free Rad Biol Med 65: 1363-1377, 2013. PMID: 24121056. DOI: $10.1016 /$ j.freeradbiomed

34 Qiao S, Li W, Tsubouchi R, Haneda M, Murakami K, Takeuchi F, Nisimoto $Y$ and Yoshino M: Rosmarinic acid inhibits the formation of reactive oxygen and nitrogen species in RAW264.7 macrophages. Free Radic Res 39(9): 995-1003, 2005. PMID 16087481. DOI: 10.1080/10715760500231836

35 Chen W-P, Jin GJ, Xiong Y, Hu PF, Bao JP and Wu LD: Rosmarinic acid down-regulates NO and PGE2 expression via MAPK pathway in rat chondrocytes. J Cell Mol Med 22(1): 346353, 2018. PMID: 28945000. DOI: $10.1111 / \mathrm{jcmm} .13322$
36 Matthews JR, Botting CH, Panico M, Morris HR and Hay RT: Inhibition of NF-kappaB DNA binding by nitric oxide. Nucleic Acids Res 24(12): 2236-2242, 1996. PMID: 8710491. DOI: $10.1093 / \mathrm{nar} / 24.12 .2236$

37 Godley BF, Shamsi FA, Liang FQ, Jarrett SG, Davies S and Boulton M: BL induces mitochondrial DNA damage and free radical production in epithelial cells. J Biol Chem 280(22): 21061-21066, 2005. PMID: 15797866. DOI: 10.1074/jbc.M50 2194200

Received November 15, 2019

Revised January 14, 2020

Accepted January 15, 2020 